\title{
Latin Maxims and Expressions in English, Estonian and Polish Legal Language in the Aspect of Translation
}

\author{
Aleksandra Matulewska, Magdalena Wasielewska \\ Institute of Linguistics, Adam Mickiewicz University \\ ul. Międzychodzka 5, 60-371 Poznań, POLAND \\ matulewski@poczta.onet.pl, m_wasielewska@o2.pl
}

\begin{abstract}
This paper discusses the history of Latin maxims and expressions in English, Estonian and Polish legal languages and the influence of Latin on contemporary legal language and its translation. A number of maxims and expressions were examined by comparing their present meanings in those three legal systems. A selection of fifteen of them is presented in the article, namely: ab intestato, corpus iuris civilis, error iuris, fraus est celerem fraudem, ignorantia iuris neminem excusat, impossibilium nulla est obligatio, inter arma silent leges, ipso iure, lex non scripta, pacta sunt servanda, qui tacet - consentire videtur, restitutio in integrum, $m$ sub iudice, and summum ius summa iniuria. The term Actio Pauliana which is used in the bankruptcy law is used here to show how translators may use Latin terms in order to find proper translation equivalents. Finally, the authors point out the differences in pronunciation and spelling of Latin maxims and expressions in English, Estonian and Polish.
\end{abstract}

\section{Introduction}

The aim of this paper is to describe some Latin maxims, terms and expressions used in legal language. The impact of Latin on three languages, namely: Polish, Estonian and English, is discussed here.

B. Wróblewski [99] distinguishes język prawny (the language of law), which is defined as the language of legal instruments, and język prawniczy, which is used to discuss, describe, and analyze statements in the language of law. From the linguistic point of view then jezyk prawniczy is the metalanguage of law [67: 185]. Although Kielar [45] suggests the following equivalents: 'the language of the law' as the former and 'the lawyers' language' as the latter, and Roszkowski [78] uses the following English equivalents: 'the language of the legislator' understood as język prawny and 'the juristic language' as jezyk prawniczy, we shall use the terms (i) the language of law and (ii) the metalanguage of law in this paper.

\section{The Brief History of the Impact of Latin on English}

The Roman conquest of the British Isles actually started in 55 and 54 B.C. At first the invaded area was relatively small but one hundred years later (in 43 r. A.D. the area included England, Wales 
and a major part of Scotland). The progressing fall of the Roman Empire led to the withdrawal of legions from the territory in 407 A.D. What is surprising is the fact that in contrast to Continental Europe the impact of the presence of the Roman Empire on the British Isles on the political system, which developed later, was insignificant but the impact of Latin, its alphabet and the introduction of Christianity cannot be ignored [57: 149].

Latin appears on the British Isles again one century later together with Christianity. In the process of Christianization the legal vocabulary is enriched. Terms, which were initially used only in the religious context gradually acquired a new meaning, e.g. the following words of Latin origin still function in modern English: cell, offer, title [68: 50].

The next period, very important as far as the legal and political systems are concerned, is the Norman Conquest. Melliknoff [68: 65] writes that "The written languages of the law after the Norman Conquest were Latin and English, with Latin far in the lead. French was not yet in the running. At the time of the invasion, acts of the French King's chancery were still recorded in Latin, and we have no records of any Norman laws of that period written in French" Out of 487 legal documents which survived till our times dated back to 1066-1100 19 are in English, 9 are in both English and Latin and the remaining 459 are in Latin only. The popularity of Latin may be justified by the fact that the governing class wanted to formulate the law in a language which would not be understood by common people. What is more, the judges (who were usually the clergymen) first and foremost used Latin. Although William the Conqueror separated church and lay courts but in both types of courts the judges were clericals. That is why there are numerous terms from Latin in English such as: indebitatus assumpsit, corporeal, incorporeal, notary, protonotary, citation, exception, perjury, suborn, fieri facias, habeas corpus, mandamus, quo warranto, subpoena, supersedeas, verdict, donor, legacy, homicide, testis, testify, testimony, testator, testament, advocate, proctor =procurator, attorney, solicitor, counsel, counselor, narrator, billa vera, ambidexter [68: 71-82] (some of them were borrowed from Latin directly but others were borrowed from Latin via Old French).

After the Battle of Hastings (1066), in which William the Conqueror defeated King Harold the English language was gradually replaced by French and Latin and that is way it nearly stopped functioning as a language of literature or documents. The factual data and chronicles in English which survived till our times were secretly written in monasteries [57]. English was considered to be the language of the commonalty. The upper classes of society used French and Latin. English was mainly used in oral communication. The problems were enhanced by the lack of official ortography, e.g. the word law was spelled in various ways e.g.: lach, laewe, lagh, laghe, laha, lau, lauh, law, or laugh [68: 84].

Lipoński [57] points out that at the end of $11^{\text {th }}$ century the historical writing in England started to be created by the so-called chroniclers of the Anglo-Norman period. They used Latin. The most important works written in Latin from the $11^{\text {th }}$ and a2th centuries are Historia regum, Historia rerum Anglicanum (1066-1098), Chronica (1173-1203), Vita Anselmi, Historia Anglorum, De gesti regum Anglorum, and Historia regum Britanniae (about 1136).

Melliknoff [68] points out that English became used by all social classes in the second half of the 13th century. From then on it gradually started to dominate over French and Latin. Finally, it was introduced to the school curricula in the $14^{\text {th }}$ century. Lipoński [57: 489] states that the defeat of French is solemnized by the famous sentence written by George Durham in his letter (dated 1400) to king Henry IV, in which the author confesses that he writes his letter in English because he understands this language better than Latin or French.

Nevertheless the impact of the simultaneous functioning of three languages (English, French and Latin) resulted in another linguistic phenomenon, namely, using synonymical terms from those languages which function as fixed syntagmas e.g.:

- Deem and consider

- Final and conclusive

- Fit and proper

- Mind and memory

- New and novel 
- Peace and quiet

- Will and testament

- Rest, residue and reminder.

David Melliknoff [68: 58] describes the complex origin of English in a very accurate way: ,after a French marriage or an Old English (O.E.) wedding, you have entered into O.E. wedlock, which is the same as French marriage (as an institution) or the gratuitous complication matrimony (Latin via Old French). You may buy a home in Old English or purchase it in French, take possession in French and own it in Old English. You have an Old English child, who will also be a French infant and a Latin minor. You write an O.E. will or a Latin testament. In it you dispose of your French property which was once the same as O.E. goods or French chattels, until both goods and chattels were limited to movables. There was also a time when you could bequeath (O.E.) everything you could devise (French), and you could once seriously devise a bed. In Old English you forgive debts, and at one time you could pardon them in French. An O.E. sheriff or a French constable arrests you for French larceny which is the same as O.E. theft or stealing. You get an English lawyer or a French attorney who goes to a French court, approaches O.E. bench, and speaks to the French judge. The O.E. witnesses take an O.E. oath and swear in Old English that their French evidence is not English hearsay. The O.E. foreman of a French jury brings in a French verdict of O.E. guilty, and in a former day you might end up on an O.E. gallows or a French gibbet, unless you got a French pardon".

In the $16^{\text {th }}$ and $17^{\text {th }}$ centuries there was a tendency to translate Latin documents into English. Unfortunately, those texts were translated word-for-word. The result was quite disastrous. A contemporary translator can easily imagine the outcome if we take into consideration the word order characteristic of Latin and English.

\section{History of Latin in Estonian}

The territory of contemporary Estonia was inhabited by Finno-Ugric tribes which did not develop their own state organization till the 13th century. The land was divided into districts, which where governed by local governors who imposed their own laws. At the turn of the 9th century the fights for influence in Estonia started in connection with a visible economic development. Initially, the commercial settlements were established by Scandinavians. Later, in the $10^{\text {th }}, 11^{\text {th }}$ and $12^{\text {th }}$ centuries the territory was raided by Russian princes who annexed the territory of Estonia to the Varangian state with their capital in Kiev imposing their own laws and tribunal dependence in the $11^{\text {th }}$ century. Later after the decline of Kiev Estonia was conformed to Novogrod.

Latin came to Estonia from many countries together with Christianity. There were attempts to graft Christianity in eastern rite in the 11th century: 'Orthodox Estonians derive from two groups: Estonian people from the southeastern Petserimaa area belonging to Psków in the Middle Ages from which Christianity in the eastern rite arrived as early as the $11^{\text {th }}$ century and serfs who converted to the Orthodox Church in the $19^{\text {th }}$ century thinking that in that why they would get land from the tsar [13]. The next attempt to Christianize the territory of Estonia was made by the Swedish and Dutch in the $12^{\text {th }}$ century. However, the completion of that task, that is compulsory Christianization and conquest of Estonia, fell to the Teutonic knights at the beginning of the $13^{\text {th }}$ century. The bishop of Riga, Albert von Buxhövden, was in charge of Teutons who conducted the conquest of the Latvian territories. In the second and third decades of the $13^{\text {th }}$ century $(1208-1227)$ the southern part of contemporary Estonia and Osilia was occupied in the wake of the conquests of the bishop and the Order of the Brethren of the Sword. As Teutonic power turned out to be insufficient, the bishop, Albert, made an alliance with the Dutch King who captured the district of Revla in 1219. As a result of warfare the territory of Estonia was divided between the conquerors: (i) the northern part - the Duchy of Estonia (Harjumaa, Järvamaa and Virumaa) - was controlled by the Dutch, (ii) the southern part - Livonia - was controlled by the bishops of Dorpatu and Osilia and the Order of the Brethren of the Sword. 
The first decades of the $13^{\text {th }}$ century were described in Heinrici Chronicon Livoniae. There are no sources concerning the second half of the $13^{\text {th }}$ century and the whole $14^{\text {th }}$ century.

Latin borrowings appeared in Estonian in connection with the Christianization. The following words were incorporated into Estonian via German or Finno-Baltic languages: [monastery] est. klooster - ger. Kloster, [church] est. kirik (Finno-Baltic) - ger. Kirche, [baptismal] est. rist (FinnoBaltic, or Old Russian - krbstb) - ger. Taufe, [to baptize] est. ristima (Finno-Baltic) - ger. taufen, [Christian] est. Kristlane - ger. Christ, [Mass] est. missa - ger. Messe, [offering] est. ohver - ger. Opfer.

Besides the borrowings connected with the Christianity we note in Estonian the borrowings from Latin connected with religion only indirectly such as: Latin, est. ladina, March, est. märts, May, est. mai, school est. kool; directly from German: colour est. värv, coat of arms/crest/emblem est. vap, silk est. siid, knight est. rü̈̈tel, etc. Those borrowings inform us about frequent trade contacts with the Germans as well as German influence on the organization of social life.

The territory of Estonia was occupied by the subsequent raiders. Between 1236 and 1346 the northern part of Estonia belonged to the Dutch. 'Similarly, the Dutch vassals in the northern part of the country enjoyed significant independence granted by the King. The Estonians lost their own seniority, who were assimilated or became extinct and remained only pheasants. The knighthood, clergy and bourgeoisie were of German origin. However, Estonian played a very important role. The Order bought from the Dutch king the districts of Harjumaa and Virumaa in 1346. As a result, the whole Estonia belonged to the Knights of the Cross' [33].

Estonia was invaded by the Dutch, Poles, Swedish in the next centuries. However, Estonians preserved their language and cultural heritage. The fact that there were the monasteries of Cistercians (Padise, Kärkna, Tallinn and Lihula), Dominicans (Tallinn and Tartu) and Franciscans (Tartu, Viljandi and Rakvere), had a significant influence on the impact of Latin on Estonian and the development of Latin writings. Other orders which were very popular in Western Europe never reached Estonia. However, the masses were said in Low German or Estonian in all churches in Tallinn as soon as the $15^{\text {th }}$ century.

The Russian invasion took place in the $16^{\text {th }}$ century. The Estonian nobles who inhabited the territory of Harju, Järva, and Viru after the conquest of Tartu and Narva by the tsar, Ivan the Terrible, in 1558 surrendered to Sweden in 1561. The last master of Livonia, Gothard Kettler, surrendered then to Poland and Lithuania. The remaining part of Estonia fell to Sweden in the wake of the war between Sweden and Russia in 1583. Saaremaa remained Dutch.

'In 1600 Sigismund III Vasa - the king of Sweden and Poland incorporates Estonia to Poland. The seizure of Estonia resulted in a war with Sweden. As a result of the war, Swedish took up Parnawa in 1621 and Tartu in 1625 (...). A high school was founded in Tallinn in 1631. Gustav II Adolf founded a university in Dorpat in Tartu in 1632. Estonian was taught at university, and the sons of peasants were accepted as pastors. (...) A chain of diocesan schools was created and the teachers were educated to meet the schools' requirements between 1690 and 1700. Carl XI paid for publishing the first book in Estonian (the New Testament). Johan Hornung established Estonian spelling and cleaned the language from German traces. The reformation and development of education, economy and culture came together with the national Renaissance which, nevertheless, was completely destroyed by the war waged between 1700 and 1721' [33].

The first book in Estonian was published in 1535. The Bible was translated into Estonian in 1739. 'However, books in Estonian were published as soon as the 16th and 17th centuries. There were about 45 books published then, still in one out of two different dialects (the northern one and the southern one) between 1631 and 1710' [39].

As a result of the fact that the tsar, Peter I, took over the power in 1710, the German nobles gained autonomy. All the administration, police, and legal system of the country fell into the hands of German barons and the noble families registered by them between 1750 and 1760. It did not mean legal liberties, though. All the resolutions required the tsar's approval, which was usually issued by generals. On 25 of May 1816 the national Seym passed the bill which made peasants choose names for themselves, and as it was usually done by their masters many Estonians got German and Swedish names. 
The development of the national language was aided by the Church, which required the ability to read from every single person who wanted to consume the Host from 1730 on. However, the level of education was very low and the teachers were usually sacristans. 'Estonian Landtag introduced obligatory education and ordered the foundation of elementary schools in all places with more than one thousand inhabitants as late as 1816. The language used was Estonian. The curriculum comprised no more than religion, reading and writing classes. Between 1845 and 1848 a catechism was published in Estonian and Livonian. Estonian was introduced into the curriculum of a seminar in Psków. The laws and resolutions of authorities were announced also in local languages. In the $60 \mathrm{~s}$ of the $19^{\text {th }}$ century the following types of schools were established: communal, higher parish and municipal, regional ones and grammar schools. Moreover, the process of education of professional teachers started, depriving the Church of its teaching monopoly. The national authorities also established schools with Russian between 1870 and 1880 . Apart from those schools and a school for girls with Estonian in Parnava the rest of schools had German as a teaching languages and Estonian with a status of a supplementary language (only during the first years of education) about 1880' [33].

Robert Jakobson (1841-1882) demanded teaching subjects in Estonian and introducing Russian in connection with a dominant role of German in the second half of the $19^{\text {th }}$ century. Nevertheless, German remained an official language till 1880.

Alexandre III ascended the throne in 1881 and after the period of Germanization there followed a period of Russification. As a result, the state judicial system was introduced. Russian became an official language and in the wake of educational system Russification Estonian was limited to the role of a supplementary language (that is in the first two grades religion was taught in Estonian and there were some classes of Estonian as a native language) again. Russification of Dorpacky University took place gradually from 1889.

The beginning of the $20^{\text {th }}$ century is the period of emigration for money far into the Russian territory and initiatives to create a sovereign state. A short period of independence from the $24^{\text {th }}$ January 1918 to November 1918 did not enable the development of a legal system and codification of laws. The Democratic Republic of Estonia was proclaimed in 1919. Since that time the influence and domination of the USSR have started. The occupation of the country by the USSR made Russian an official language again and any changes in laws were the changes of the USSR's laws. Estonia regained its independence on the $20^{\text {th }}$ of 1991.

We cannot ignore the importance of rural people who kept their language, customs and rituals and resisted the new religion which came from the West, on the one hand, and the Baltic Germans, on the other hand. The creation of culture included the destruction of Estonian culture and creation of a mixed German and Estonian culture with Polish, Swedish and Russian elements. The Germans controlled the majority of Estonian territory, they introduced their own language, laws and they shaped social relations. In the $19^{\text {th }}$ century due to the impact of education the national conscience boosted among Estonians [39].

So complicated history of the territory of contemporary Estonia and its inhabitants resulted in frequent changes in Estonian legal system depending on the changes of occupants and governing authorities. Consequently the presence of Latin in Estonian depended on the legal system of the invaders.

In contemporary Estonia the judicial proceedings is conducted in Estonian or in any other language as far as the parties and the court know that language sufficiently (usually it concerns Russian). The parties who do not know the language of the proceedings may participate in it via translators. Latin finally disappeared from court houses. It is no longer used in codes and collections of laws. The only exception are the European Union laws, which are translated from English into Estonian where occurring Latin expressions and terms are kept. That is the only case in which Latin appears in Estonian legal texts. 


\section{The Brief History of Latin in Polish}

The existence of statehood is a fundamental factor influencing the development of law and legal system. From the dawn of history there were two state creating centers in the Polish land, namely: the southern one - (i) the land of Wiślanie comprising of the territory by the upper Vistula, with the capital city of Kraków or Wiślica, and later probably the land of Slężanie tribe, that is the future Silesia (Śląsk); and (ii) the northwestern land of Polanie. The land of Wiślanie and Ślężanie was incorporated into the Great Moravia, and then Bohemia [93: 22]. That is why the second statecreating center played the major role in the process of state formation. Polanie occupied the territory of the future Wielkopolska (Great Poland) by the Warta River, Obra River and Prosna River. 'Their name derives from the farmlands, which were in abundance in the territory inhabited by them: Polanie that is simply $<<$ the inhabitants of fields, that is the inhabitants of the land where the arable fields predominate>>. (...) Kruszwica by Gopło Lake may have been the main center, but later it was Gniezno, Ostrów by Lednicki Lake, and Poznań' [93: 22]. That was the place where the political thought was born, the thought which launched the transformations leading to the unification of lands of the tribes sharing similar languages under one centralized authority.

We may assume that the formation of the state was one of the most important factors which influenced the fact the Polish language started emerging out of Lechicki dialects. The closure of the land by the state boundaries influenced, in a natural way, the development of language and national conscience. The state of Polanie was formed in that way. Polanie were called (i) Palanii, (ii) Polonii, and finally (iii) Poloni in Latin sources. This name was used to refer to all inhabitants of the state for the first time in the Life of Saint Adalbert at the turn of the $10^{\text {th }}$ century. Bolesław Chrobry was called dux Palaniorum, that is the prince of Polanie (the prince of all Poles) in the same document.

The second vital factor, as far as the development of language and law is concerned, is the acquisition of Christianity in the Latin rite in 966. The development of the church institution in the wake of Christianisation strengthened the state. Besides, Poland adopted alphabet, which was unknown there prior to the acquisition of Christianity. 'The hypothesis was advanced in the past that there was a Slavonic runic alphabet similar in its form to Germanic or Celtic runes prior to Christianisation. However, there is no scientific proof for this hypothesis. Nowadays that is fiction. Thus, there is no denying that the alphabet came to Poland together with the christening of Poland' [93: 27]. Thus, as result of Christianisation the Poles adopted the Latin alphabet which was subjected to the adaptation according to the needs of the Polish language. What is more, Poles adopted Latin as a universal language of Christian culture in its Roman 'variety.' It is worth noting that 'in the territory of Poland in the first centuries after the christening only Latin texts were written and later Latin writing prevailed and outnumbered the minor written output in a native language' [93: 27]. Consequently, it is assumed that Latin was the factor suppressing the development of the Polish language on the one hand, and it was the factor stimulating that development on the other hand, because 'the requirements of religious propaganda among common people made the higher centers of church activities such as Episcopal curiae, abbeys, convents and monasteries take an interest in a native language, its usage and even cultivation' [50: 22]. It was due to the fact that the lack of understanding of Latin among different social classes in a specific way stimulated the development of a native literary language. At the beginning of the statehood Latin was a language of the church rites, and education which at that time was in the hands of the clergy. Initially, the monastic and cathedral schools were elitist but with time they were transformed into primary parish schools. Latin was the main language taught at schools but Polish was introduced as an auxiliary language. All laws were written in Latin. The monopolistic character of Latin in belles-lettres and commentaries was overcome no sooner than the Renaissance. Nevertheless, the final victory of Polish over Latin took place in the Enlightenment. Although the fact that the major part of society in the Middle Ages did not understand Latin was a stimulus for the development of the native language, as it was necessary to supplement Latin texts with Polish texts not only in liturgy (translations of everyday prayers, Psalters, the Bible, and religious songs) but also in social life (translations of legal codes, etc.), there were no or a few sermons in Polish as long as the $14^{\text {th }}$ century. We may assume that Latin reigned in this field. 
The vocabulary of each language is constantly enriched. Borrowings are one of the methods of vocabulary enrichment. Christian terminology develops and pervades at the times of Christianity. 'The following words came from Latin into Polish via Bohemian: 'pacierz' [prayer] (from the first words of the Lord's Prayer: pater<noster>), pogan(in) [pagan] from a Bohemian word: pogan, nowadays pohan, from a Latin word: poganus $<<$ the inhabitant of a village, that is for Chritianised Romans: a non-Christian, ....>> and others' [93: 53]. Although some words such as: birzmować, [to confirm] (later bierzmować), klasztor [monastery/convent], kościót [church], krzest [bapism] and krzcić [baptize] as well as their derivatives: krześcijanin [Christian] etc. (the initial $k$ - was replaced with ch- no sooner than in the 16th century), msza [mass], nieszpór [vespers], ofiara [offering], ottarz [altar], opat [abbot], pielgrzym [pilgrim], proboszcz [rector], przeor [prior], żegnać [to cross oneself], and others came to Polish via two languages, namely from Latin, via German, and then via Bohemian [93: 53-54], some of the terms (biskup [bishop], jatmużna [alms], kruchta [vestibule], mnich [monk], and many others) came to Polish from Greek via Latin then via German and finally via Bohemian. A significant part of terminology came from Greek via Latin and via Bohemian e.g. aniot_[an envoy]: gr. Angelos,- lat. angelus (in the Middle Ages anielus) - Bohemian anjel - pol. anjot; ewangelia [Gospel, the good news of salvation in Jesus Christ]: gr. Euangelion, - lat. evangelium (in the Middle Ages evanjelium) - Bohemian evanjelijum - pol. evanjelija - later evangelija; as well as apostot [apostle], dyjabet [devil], kolęda [carol] and others.

Apart from borrowings connected with Christianity we also find in pre-literate Polish ones from Latin connected with Christianity indirectly: tacina [Latin], sobota [Saturday], marzec [March], maj [May], szkoła [school], via Bohemian or directly via German: barwa [colour], bursztyn [amber], chwila [moment], herb [coats of arms/emblem/crest], jedwab [silk], perta [pearl], rycerz [knight], etc. They prove that there were trade contacts between Poles and Germans and that German influence in the field of social life organization existed [93: 52-54].

Having discussed briefly the history of the introduction of Latin in Poland let us take a closer look at the documents which survived till our times and which confirm the major impact of Latin on literature, and writing connected with legislation.

One of the first monuments we would like to mention here is Bulla gnieźnieńska [the Golden Bull of the Polish Language] from 1136, containing more than 400 proper and local names in Polish despite the fact that the whole document which was published by the pope, Innocent II, was written in Latin. Earlier documents written in Latin e.g. Dagome iudex contain a minimal number of Polish names. Information on Polish law in the Middle Ages is provided via annals, lives of saints, chronicles, and letters written in Latin. Some of the oldest annals which survived till our times are Rocznik świętokrzski dawny [the Old Holy Cross Annal] written in the $12^{\text {th }}$ century after 1122 in Kraków and Kronika Galla Anonima [Chronicle by Gall Anonim] from the end of the $11^{\text {th }}$ century. There are also some important pieces of information in the following documents: Kroniki Wincentego Kadtubka [Chronicles by Wincenty Kadtubek] (about 1220), Kronika Wielkopolska [Chronicle of Wielkopolska] (about 1295), and the most important Kronika Jana Dtugosza [Chronicle by Jan Dtugosz] written from 1455 to 1480. Nevertheless, those documents are not direct sources of the cognition of law.

Initially Polish law was moulded as a result of everyday legal practices, the basis of law formation were juridical activities and court rulings. That is why individual cases influenced the content of the law [62: 15]. What is more, among the direct sources of law there were priviledges (Przywilej trzebnicki [the Priviledge of Trzebnica] issued in 1204 by the prince, Henryk Brodaty, for Trzebnica monastery), and property books (księgi uposazeń) as well as documents issued by dukes, nobles, and collections of laws. The most famous sources which survived till our times include the property books:

(i) Księa henrykowska [the Property Book of Henryków] (1270-1310, which contains the history of the monastery and the monastery's property including circumstances of donations and purchases, e.g. documents certifying the performance of legal actions; there are 120 names of places - some of them with etymology - in this document), 

the City of Wroctaw] (1302-1319, which contains the list of bishop's property including income and data concerning people inhabiting the area); and

(iii) Księga uposażen diecezji krakowskiej [the Property Book of the Diocese of the City of Kraków] (15th century, written by Jan Długosz with the description of the diocesan estate).

Documents issued by dukes (legal documents concerning the management of the state and court files) as well as private documents which are divided into:

(i) cartae - statements of intentions concerning transfers of the estate or stating the creation of the legal relation between the parties;

(ii) notitiae - confirmations of the performed legal acts; as well as collections of laws.

Private documents were usually executed to regulate civil matters. The most valuable collection of common law is Zwód also called Ksiega elblaska [the Book of the City of Elblag] executed after 1253 but before 1320. It is a collection of Polish criminal law and proceedings, and it contains only minor norms regarding civil matters.

The rotas of court oaths (roty przysiag sadowych) mentioned hereinabove are legal documents which were written in Polish and Latin (for Poznań district from 1386, and for Kraków district from 1397). They were testimonies of parties and witnesses given in court under oath. Court books were written in Latin, but the texts of testimonies were sometimes recorded in Polish. There were also translations of legal codes.

We shall also mention the following sources of law:

(i) statutes (statuty) e.g. Statut wielkopolski [the Great Poland Statute] dated to 13561362; Statut wiślicki [the Statute of Wiślica]. Świętosław from Wocieszyn translated the Statute of Wiślica from Latin into Polish in 1449. In the second half of the $15^{\text {th }}$ century the formulas of oaths taken by administrators of villages, jurors, consuls, and municipal mechanics were written in Polish. However, Latin survived in statutes till modern times e.g. Statut Laskiego [Statute by Laski] from 1506 is a collection of laws in Latin (volume one was devoted to Polish law and volume two - to German law).

(ii) privileges granted to the nobles in $13^{\text {th }}$ century and later which comprised important provisions concerning judicial matters and many covenants stating the favorable legal conditions for the nobles. Among the most important privileges there are:

- budziński privilege granted in 1355,

- $\quad$ koszycki privilege granted in 1374 ,

- piotrkowski privilege granted in 1388 ,

- czerwiński privilege granted in 1422,

- warecki privilege granted in 1423 ,

- jedlińsko-krakowski privilege granted in 1430, 1433, and

- nieszawski privilege granted in 1454.

Municipal and rural laws were written in Latin as well. Among municipal books there are:

(i) ksiegi tawnicze [acta scabinalia] kept by the municipal bench. The oldest are dated to the beginning of the $14^{\text {th }}$ century. They comprised the records of litigatious and non-litigatious matters heard by the bench.

(ii) ksiegi radzieckie [acta consularia] written later than the former and comprising records of files such as: administrative, judicial and normative ones.

Information on rural law may be found in privileges, location documents, and rural court books. Latin was used in those documents as long as the $16^{\text {th }}$ century, and then it was replaced with Polish. Canon law at that time was written only in Latin.

We cannot forget about the following legal documents:

(i) the collection of Polish laws of Jan Palczewski dated to 1561, written completely in Polish. The fact that it was published in Polish had a practical aspect as Polish was Poland's official language. 

ordinem alphabeti digesta. This collection was written in Latin and was widely used by the system of justice. The Polish Seym commissioned Herburt to translate into Polish statutes and privileges in a systematical order in 1564. The collection was published in 1570 under the name: Statuta i przywileje koronne z łacińskiego języka na polski przetożone, nowym porzadkiem zebrane $i$ spisane [the Statutes and privileges of the Crown Translated from Latin into Polish Written and Collected in a New Order]. However, the Lubuski Seym did not approve the collection due to its internal chaotic character and lack of systematization.

Legal literature of the $16^{\text {th }}, 17^{\text {th }}$ and $18^{\text {th }}$ centuries was mainly in Latin e.g. Processus iudiciarius from 1612 by Teodor Zawacki. At the end of $18^{\text {th }}$ century Polish finally strengthened its position in law and Polish started prevailing in all legal documents.

At the time of partition of Poland the country had to accept the law of invaders e.g. in civil law [62: 125-136].

In the Prussia annexation after the first partition of Poland which took place in 1772 Polish laws were repealed and the following were introduced: Prussian Landrecht from 1721, the first volume of Corpus Iuris Friderciani from 1748 (in marriage and guardianship matters), and Silesian mortgage laws from 1750, as well as other minor legal instruments. During the next two partitions which took place in 1793 and 1795, initially the Polish laws were kept, but in 1797 they were repealed completely and replaced with the Prussian Landrecht from 1974. Polish law remained in force in such matters as testate succession, life estate, subject and municipal relations, as well as church fees.

In the Austrian annexation the Polish laws were also initially kept, but in 1775 the process of the introduction of Austrian laws began. Finally, a civil code which completely repealed Polish laws was introduced in 1797. Similar fate met criminal and commercial laws during the annexations.

In 1808 in the Grand Duchy of Warsaw formed in 1807 the Napoleonic Code from 1804 was introduced.

Having regained its independence in 1918 Poland started the process of standardization of law as since then the following laws were applied: Austrian, German, French, Russian, and Hungarian. 'The sources of law in individual territories were the following:

(i) the $2^{\text {nd }}$ and $3^{\text {rd }}$ book of the Napoleonic Code, mortgage laws from 1818 and 1825, Civil Code of the Kingdom of Poland from 1825 and marriage law from 1836 in the territory of the former Kingdom of Poland;

(ii) the $10^{\text {th }}$ volume of Zwód praw Cesarstwa Rosyjskiego [the Collection of Laws of the Russian Empire] from 1836 in the territory of former Russian annexation;

(iii) the German Civil Code from 1896, in the territory of the former Prussian annexation;

(iv) the Austrian Civil Code (ABGB) from 1811in the territory of the former Austrian annexation; and

(v) the Hungarian law, and since 1923 ABGB in the territory of Spisz and Orawa.

The sources of civil procedure were the following:

(i) the Russian statute on civil procedure from 1864 in the territory of former Russian;

(ii) the Prussian code of civil procedure from 1877 in the territory of former Prussian annexation; and

(iii) the Austrian code of civil procedure from 1895 in the territory of former Austrian annexation.

The sources of criminal law were the following:

(i) the Russian criminal code of Tagancew from 1903 in the territory of former Russian annexation;

(ii) the Criminal code of the Second Reich from 1871 in the territory of former Prussian annexation; and

(iii) the Austrian criminal code from 1852 in the territory of former Austrian annexation.

The sources of criminal procedure were the following: 
(i) the Russian statute on criminal procedure from 1864 in the territory of former Russian annexation;

(ii) the Prussian code of criminal procedure from 1877 in the territory of former Prussian annexation; and

(iii) the Austrian code of criminal procedure from 1873 in the territory of former Austrian annexation.

The sources of commercial law were the following:

(i) the French commercial code from 1807 and supplementary Russian statutes in the territory of former Russian annexation;

(ii) the Prussian commercial code from 1897 in the territory of former Prussian annexation; and

(iii) the Austrian commercial code from 1861 in the territory of former Austrian annexation' [62: 173-174].

In the face of such a diversity of applied legal instruments and used legal languages it was necessary to unify the legal system in order to provide a better integrity of the state. Unification was supposed to come along with a new codification.

Nowadays the official language in Poland is Polish and the impact of Latin on the language is the result of tradition and history. Therefore there are certain vocational groups which are prone to use Latin (e.g. laweyrs, doctors, etc.).

What is more, there are legal acts which regulate the use of non-Polish words in Poland such as: Act of 7 October 1999 on the Polish language (Ustawa o jezyku polskim), Regulation by the Minister of Internal Affairs and Administration of 18 March 2002 on the Cases in which the Names and Texts in Polish May Be Accompanied by Their Translations into Foreigna Language (Rozporzadzenie Ministra Spraw Wewnętrznych i Administracji w sprawie wypadków, w których nazwom i tekstom $w$ języku polskim moga towarzyszyć wersje $w$ przektadzie na język obcy) and Regulation b'y the Prime Minister of 20 July 2002 on 'the Principles of Legislative Technique (Rozporzadzenie Prezesa Rady Ministrów w sprawie 'Zasad techniki prawodawczej'). The latter states:

‘ 8. 2. W ustawie należy unikać posługiwania się:

1) (...)

2) określeniami lub zapożyczeniami obcojęzycznymi, chyba że nie mają dokładnego odpowiednika w języku polskim;

3) nowo tworzonymi pojęciami lub strukturami językowymi (neologizmami), chyba że w dotychczasowym słownictwie polskim brak jest odpowiedniego określenia.'

‘ 8. 2. In statutes one shall avoid using:

1) (..)

2) foreign terms or borrowings with the exception of situations in which there are no exact counterparts for them in Polish;

3) newly coined concepts or language structures (neologisms), with the exception of situations in which there has been no suitable term in Polish so far.'

This internal restriction is to protect Polish against excessive influence of foreign languages, and it is to provide legibility of Polish statutory instruments. However, it is extremely difficult to avoid foreign influence. Nowadays, Latin as a language of international communication in languages for special purposes (e.g. legal and medical ones) is squeezed out by English which pervades into almost all spheres of our lives. It happens so due to the technological progress, development of new industrial branches, electronics, new sciences, and methods and procedures applied in order to perform many activities of everyday life. That is why in the Civil Code there is e.g. umowa leasingowa (contract of lease with an option to purchase), in computer sciences we find such terms as: notebook, screen, hardware, on-line, software, CD-ROM, chip, chipset, and many others. The existence of such vocabulary is justified by (i) language economy which imposes 
the introduction of unambiguous terms, which should be short and precise at the same time, as well as (ii) language usage which may become a norm.

\section{Translation methods used}

This paper deals with Latin in law and it is intended to show the ways in which we may use Latin in translation of legal texts.

If we take English as a target language it may happen that the target reader comes from the United States of America, the United Kingdom or is using this language as the language of international communication. The country of reader's origin may determine equivalents a translator is obliged to use.

D. Kierzkowska [49: 88] specifies three types of receivers:

1) a close receiver who knows or wants to know the source-language culture (e.g. a businessman, lawyer, translator, interpreter),

2) a distant receiver who does not know or want to know the source-language culture (e.g. a tourist), and

3) a self-specified receiver who uses his own terminology.

Furthermore, D. Kierzkowska [49: 90] describes four categories of usage imperatives which are imposed on a translator with the following examples:

1) international usage: pol. nieruchomość

ang. immovable property

2) national usage:

pol. nieruchomość ang. real property

3) (traditional) local translation usage:

pol. nieruchomość ang. real estate, and

4) customer usage

pol. nieruchomość ang. realty.

Sometimes it is extremely difficult to find equivalents and then translators have to coin new terms. Such a new-speak is not always accepted and what is more it is usually criticised. What we would like to propose is to check first whether it is possible to find existing term, in the target language via Latin. It turns out that Latin is a kind of international language not only in medicine and biology-related sciences but also in law. So if we want to find international or target-language oriented (denotative) equivalents then it is possible to use Latin.

\subsection{Example}

Let's take a Polish concept known as 'skarga paulian'ska' from the lawyers' language. In Latin it is called 'Actio Pauliana'. It stems from at least the 9th century and is reflected in all developed insolvency laws. It is used when a debtor is accused of a deliberate intention to defraud creditors. In Louisiana it is called 'revocatory action'. In the USA it is generally called 'revocation action', and in the UK it is called 'fraudulent action' or 'action on the basis of intentional fraud of the creditors'. But it turns out as well that apart from those denotative equivalents in all those countries lawyers refer to it as: in Poland 'actio Pauliana' and in the European Union, USA, and UK as 'the Actio Pauliana'. So in this case we may stipulate that this Latin term may serve as an international equivalent. 


\section{Specimens of Latin maxims in legal language}

Latin

\section{Polish}

English

Estonian

Commentary ab intestato

dziedziczenie ustawowe

[statutory succession; intestate succession]

in the civil law: from an intestate, from the intestate, in case of intestacy.

testamenti tegemata

[without last will and testament, used in case of intestate succession]

English - used in the language of the law as well as the metalanguage of the law.

Polish - Latin used in the metalanguage of the law only; in Polish statutory texts: dziedziczenie ustawowe [statutory succession].

Estonian - used in the metalanguage of the law only.

Latin

corpus iuris civilis

Polish

English

Estonian

Commentary

Latin

error iuris

Polish

English

Estonian

Commentary główne prawa cywilne/obywatelskie

[the main body of the civil law]

Corpus juris civilis

The body of the civil law. The system of Roman jurisprudence compiled and codified under the direction of emperor Justinian, in A.D. 528-534. This collection comprises the Institutes, Digest (or Pandects), Code, and Novels. The name is said to have been first applied to this collection early in the seventeenth century.

Keiser Justinianuse (VI s) ajast pärinev Rooma õiguse kogu.

[the collection of Roman law dated back to the times of emperor Justinian (6th century)]

English - history of law. The change in spelling as Latin ,iuris" changes into ,juris”; used in the metalanguage of the law.

Polish- history of law; contemporary civil law; used in the metalanguage of the law.

Estonian - history of law; used in the metalanguage of the law. błąd prawa, błąd co do przepisów prawa

[error of law, a mistake of the law]

Error juris nocet- Error of law injures. A mistake of the law has an injurious effect; that is, the party committing it must suffer the consequences.

juriidiline eksimus $\mathrm{v}$ viga

[juristic error/mistake]

Polish - used in the metalanguage of the law.

English - used in the metalanguage of the law.

Estonian - used in the metalanguage of the law; literal translation in comparison with Polish and English the form changes from "A mistake of the law" to "juristic mistake". 
Latin

Polish

English

Estonian

Commentary

\section{fraus est celere fraudem}

oszustwem jest ukrywanie oszustwa

[it is a fraud to conceal a fraud]

It is a fraud to conceal a fraud.

pettuse varjamine on (samuti) pettus.

[it is also a fraud to conceal a fraud]

English - used in the metalanguage of the law; commercial law.

Polish - Literal translation; used in the metalanguage of the law. Reference to the language of the law:

por. artykuł $86 \S 2$ kodeksu cywilnego: Podstęp osoby trzeciej jest jednoznaczny z podstepem strony, jeżeli ta o podstępie wiedziała i nie zawiadomita o niej drugiej strony (...)" - concerns parties to the contract.

Estonian - literal translation; used in the metalanguage of the law.

\section{Latin}

Polish

ignorantia iuris neminem excusat = Ignorantia iuris nocet

nieznajomość prawa nie zwalnia od odpowiedzialności [ignorance of law excuses no one]

English

Estonian

ignorantia juris nocet

Ignorance of law excuses no one.

ignorantia iuris neminem excusat

seaduse mittetundmine ei vabanda kedagi.

[ignorance of law excuses no one]

Commentary

English - used in the metalanguage of the law.

Polish - used in the metalanguage of the law.

Estonian - literal translation; used in the metalanguage of the law.

\section{Latin}

impossibilium nulla est obligatio

Polish

English

Estonian

Commentary nikt nie jest zobowiazany do rzeczy niemożliwych [there is no obligation to do impossible things] Impossibilium nulla obligatio est there is no obligation to do impossible things.

kohustusel teha võimatult ei ole jõudu. [impossible things do not create obligations] Polish - used in the metalanguage of the law. English - used in the metalanguage of the law. Estonian - literal translation; used in the metalanguage of the law.
Latin

Polish

English

Estonian

\section{inter arma silent leges}

w czasie wojny prawo milczy

[in time of war the laws are silent]

In time of war the laws are silent. It applies as between the state and its external enemies; and also in cases of civil disturbance where extrajudicial force may supersede the ordinary process of law. relvade keskel (s. o sõja ajal) seadused vaikivad [In time of war the laws are silent] 
English - used in the metalanguage of the law.

Polish - used in the metalanguage of the law.

Estonian - used in the metalanguage of the law; lexem "war" is used interchangeably with armed".

Latin
Polish

\section{English}

Estonian

Commentary

\section{ipso iure}

z mocy samego prawa

[by the law itself]

Ipso jure - by the law itself. By the mere operation of law.

õiguse enese põhja

By the law itself.

English - used in the language of the law as well as the metalanguage of the law.

LLB Family Law 2002-3

A child born out of such a relationship is ipso iure part of that 'family' unit from the moment of its birth and by the very fact of it. There thus exists between the child and his parents a bond amounting to family life even if at the time of his or her birth the parents are no longer cohabiting or if their relationship has then ended.

Polish - used in the metalanguage of the law.

Estonian - used in the metalanguage of the law.

\section{Latin}

Polish

English

Estonian

Commentary

\section{lex non scripta}

prawo niepisane lub zwyczajowe

[The unwritten or common law]

The unwritten or common law, which includes general and particular customs, and particular local laws. kirjutamata seadus. [unwritten law]

English - used in the metalanguage of the law.

Polish - used in the metalanguage of the law.

Estonian - used in the metalanguage of the law.

\section{Latin}

Polish

English

Estonian

\section{Commentary}

\section{pacta sunt servanda}

umowy są dotrzymywane w całości

[agreements (and stipulations) and contracts must be wholly observed]

Agreements (and stipulations) of the parties (to a contract) must be observed]

kokkuleppeist (lepinguist) tuleb kinni pidada.

Contracts/Agreements must be fully observed.

English - used in the metalanguage of the law; commercial law.

Polish - used in the metalanguage of the law; commercial law.

Estonian - used in the metalanguage of the law. 
Latin

Polish

English

Estonian

Commentary

Polish

English

Estonian

Commentary

Latin

Polish

English

Estonian

Commentary qui tacet, consentire videtur

Kto milczy, zdaje się zezwalać.

[He who is silent is considered as assenting]

(...), ubi tractatur de ejus comodo - He who is silent is considered as assenting, when his interest is at stake.

kes vaikib, näib nõustuvat; vaikimine on nõusolek.

He who is silent is considered as assenting.

English - used in the metalanguage of the law.

Polish - used in the metalanguage of the law.

Estonian - used in the metalanguage of the law.

restitutio in integrum

przywrócenie do stanu pierwotnego; w dawnym prawie polskim: wznowienie postepowania

[restoration or restitution to the previous condition; in Polish law: instituting the trial de novo]

In the civil law restoration or restitution to the previous condition. This was effected by the praetor on equitable grounds, at the prayer of an injured party, by rescinding or annulling a contract or transaction valid by the strict law, or annulling a change in the legal condition produced by an omission, and restoring the parties to their previous situation or legal relations.

[Maximum measure of damages awarded in the event of a marine collision is "restitution in integrum" which strictly construed limits damages to the difference in value of vessel before and after collision, but measure is equated with the cost of necessary repairs and loss of earnings while they are being made. Delta Marine Drilling Co. v. M/V Baroid Tanger, C.A.La., 454 F.2d128, 129]

In Scotland - restitution of rights. end olukorra ennistamine.

[restoration or restitution to the previous condition]

English - used in the metalanguage of the law.

Polish - used in the metalanguage of the law.

Estonian - used in the metalanguage of the law.

\section{sub iudice}

podczas procesu/śledztwa sądowego, sprawa jeszcze nie rozstrzygnięta, jeszcze rozważana przez sąd [during proceedings or investigation; undetermined case; case under judicial consideration]

Sub judice - Under or before a judge or court, under judicial consideration; undetermined.

(kohtuniku all) kohtuasja veel otsustamata olles. [proceedings/case still undetermined]

English - used in the language of the law as well as the metalanguage of the law.

Polish - used in the metalanguage of the law.

Estonian - used in the metalanguage of the law. 
Latin

Polish

English

Estonian

Commentary summum ius summa iniuria

najwyższe prawo to najwyższa niesprawiedliwość

[strict law is the greates injury]

Summum jus - strict right; extreme right. The extremity or rigor of the law. Summum jus, summa injuria; summa lex, summa crux - Extreme law (rigor of law) is the greatest injury; strict law is great punishment. That is, insistence upon the full measure of a man's strict legal rights may work the greatest injury to others, unless equity can aid.

ülim õiglus on (ühtlasi) ülim ebaõiglus

[strict right is the greatest injustice]

English - used in the metalanguage of the law.

Polish - used in the metalanguage of the law.

Estonian - used in the metalanguage of the law.

\section{Conclusion}

To sum up, the use of Latin in legal language varies from country to country. In Poland Latin is used exclusively in the metalanguage of the law. In Estonian the situation is more complicated. The Estonian laws are formulated in Estonian and do not contain Latin words. But Latin is used in the Estonian metalanguage of the law. What is more, the translation of the European Union laws into Estonian preserves Latin expressions. Latin is present in both the American and British language of the law and the metalanguage of the law. The same rule applies to the legislation of the European Union.

Furthermore, the fact that Latin maxims and expressions are used in all those languages with the same or nearly the same meaning may be very useful for the translator of those languages. Latin, in this context, turns out to be a kind of international sublanguage. Of course it does not mean that translators should overuse Latin every time they have difficulties finding translative equivalents. It seems also necessary to check the meaning and decide whether the occurring discrepancies, if any, are significant in a given context or not.

While interpreting one shall bear in mind that English-speaking communities change the pronunciation of Latin words quite significantly.

\section{Bibliography}

[1] Balcerzan, E. 1998. Literatura z literatury (strategie tłumaczy). Studia o przektadzie Nr 6. Katowice: Śląsk.

[2] Balzer, O. 1877. O potrzebie słownika prawa polskiego. Przeglad Sqdowy i Administracyjny XII.

[3] Balzer, O. 1887. W sprawie słownika wyrazów prawa polskiego. Referat na I Zjazd Prawników i Ekonomistów Polskich w Krakowie (9 IX 1887). Warszawa: Gazeta Sadowa.

[4] Bautro, E. 1935. Idea lingwistyki i semantyki prawniczej. Lwów: Dom Książki Polskiej.

[5] Bogaczowa, I. (ed.) 1992. Problemy stylu naukowego i terminologii. Wrocław: Wydawnictwo Politechniki Wrocławskiej.

[6] Bolitho, R., Kennedy, Ch. 1991. English for Specific Purposes. Hong Kong: Macmillan Press Ltd.

[7] Borkowska-Bagieńska, E., Lesiński, B. 1995. Historia prawa sadowego. Poznań: Ars boni et aequi.

[8] Bratkowski, S. 1999. Pan Nowogród Wielki. Warszawa.

[9] Campbell, H. 1979. Black's Law Dictionary. St. Paul Minn.: West Publishing Co.

[10] Chamberlin, D., White, G. 1978. Advanced English for Translation. Cambridge: Cambridge University Press.

[11] Collin, P.H., Bartnicki, K. 2001. Stownik prawa. Biblioteka profesjonalisty. Warszawa: Peter Collin Publishing i Wydawnictwo Wilga.

[12] Darski, J. 1995. Estonia. Historia, wspótczesność, konflikty narodowe. Warszawa.

[13] Darski, J. Patriarchat moskiewski traci Estonię http://abcnet.com.pl/pl/darski/kraje/estonia/cer.htm

[14] David, R. 1969. Les Grands Systemes de Droit Contemporains. Paris: Dalloz.

[15] Douglas-Kozłowska, Ch. 1997. The Articles in Polish-English Translation. Przedimek w języku angielskim. Warszawa: PWN.

[16] Dzierżanowska, H. 1990. Przekład tekstów nieliterackich na przyktadzie języka angielskiego. Warszawa: PWN. 
[17] Vääri, E., Kleis, R., Silvet, J. 2000. Võorrsõnade leksikon. Tallinn: Valgus.

[18] Faulk, M., Mehler, I.b 1994. The Elements of Legal Writing. Macmillan, USA.

[19] Filipek, J. 1968. U podstaw klasyfikacji pojęć prawnych. Krakowskie studia prawnicze RI, Vol. 1-2, pp. 31-51.

[20] Garbarczyk, P., Zimowska, K. (ed.) 2001. Wymowa prawnicza. Skrypty Becka, Warszawa: Wydawnictwo C. H. Beck.

[21] Gizbert-Studnicki, T. 1979. Czy istnieje język prawny? Państwo i prawo, Vol. 3, pp. 49-60.

[22] Gizbert-Studnicki, T. 1972. Język prawny a język prawniczy. Zeszyty Naukowe UJ, Kraków. Prace Prawnicze, Vol. 55, pp. 219-233..

[23] Gizbert-Studnicki, T. 1986. Język prawny z perspektywy socjolingwistycznej. Zeszyty Naukowe UJ, Kraków. Prace z Nauk Politycznych, Vol. 26, pp. 1-139.

[24] Gizbert-Studnicki, T. 1978. Język prawny a język etniczny. [In:] Wieloznaczność leksykalna w interpretacji prawniczej, Kraków, pp. 156-159.

[25] Grøne, H. 1992. Legal Language and the Legal Translator. Journal of Linguistics, Vol. 9. pp. 113-139.

[26] Haigh, Ch.(ed.) 1990. The Cambridge Historical Encyclopedia of Great Britain and Ireland. Cambridge: Cambridge University Press.

[27] Hałas, B. 1991. Neosemantyzm w gwarze prawniczej. Rozprawy Komisji Językowej Wrocławskiego Towarzystwa Naukowego XVII, Wrocław, pp. 203-223.

[28] Hałas, B. 1995. Terminologia języka prawnego. Zielona Góra: WSP im. T. Kotarbińskiego.

[29] Hexner, E. 1941. Studies in Legal Terminology. Chapel Hill: The University of North Carolina Press.

[30] Holvoet, A. 1991. Transitivity and Clause Structure in Polish. A Study in Case Marking. Warszawa: Slawistyczny Ośrodek Wydawniczy.

[31] http://www.ABC prawa - Prawo, Słowniki Wyjaśnienia zwrotów i wyrażeń.htm.

[32] http://www.Aforyzmy, cytaty i sentencje łacińskie (z tlumaczeniem).htm.

[33] http://www.eesti.website.pl/Historia/Kronika.htm

[34] http://www.legaltext.ee

[35] http://www.NetTax - Profesjonalny Serwis Prawny - Słowniczek łaciński.htm.

[36] http://www.Prawo karne - Linqua Latina - Slowniczek zwrotow lacinskich.htm.

[37] http://www.Serwis Prawny Ucz sie laciny.htm.

[38] http://www.vm.ee

[39] Jędras, J. Kiedy i jak uksztattowat się naród estoński http://proestonia.w.interia.pl/.

[40] Jaślan, J., Jaślan, H. 1991. Stownik terminologii prawniczej i ekonomicznej angielsko-polski. Warszawa: Wiedza Powszechna.

[41] Justyńska, J., Justyński, J. 1994. The Main Institutions of the English Legal System. Toruń: Uniwersytet im. Mikołaja Kopernika. Skrypty i teksty pomocnicze.

[42] Kalina-Prasznic, U. 1997. Leksykon prawniczy. Wrocław: Alta 2, pp. 312-313.

[43] Kalina-Prasznic, U. (ed.) 2000. Encyklopedia prawa. Warszawa: C.H.Beck.

[44] Kalinowski, S., Wróblewski, J. 1978. Zagadnienia polskiej terminologii prawniczej. [In:] Materiaty z I Konferencji Terminologicznej, 5-6 VI 1978, Warszawa.

[45] Kielar, B. 1977. Language of the Law in the Aspect of Translation. Rozprawy Uniwersytetu Warszawskiego. Warszawa: Wydawnictwa Uniwersytetu Warszawskiego.

[46] Kielar, B. 1979. Styl a język prawny. Państwo i Prawo, Vol. 3, pp. 134-135.

[47] Kielar, B. 1988. Ttumaczenie i koncepcje translatoryczne. Polska Akademia Nauk Komitet Neofilologiczny. Ossolineum.

[48] Kierzkowska, D., Rybińska, Z. (eds.) 1997. On the Practice of Legal and Specialised Translation. Warszawa: Tepis.

[49] Kierzkowska, D. 2002. Ttumaczenie prawnicze. Warszawa: Tepis.

[50] Klemensiewicz, Z. 1999. Historia języka polskiego. Warszawa: PWN

[51] Konieczna-Twardzikowska, J., Kropiwiec, U. (ed.) 1995. Między oryginatem a przektadem I. Czy istnieje teoria przekładu? Kraków: Towarzystwo Autorów i Wydawców Prac Naukowych Universitas.

[52] Korzeniowska, A. 1998. Explorations in Polish-English Mistranslation Problems. Warszawa: Wydawnictwo Uniwersytetu Warszawskiego.

[53] Korzeniowska, A., Kuhiwczak, P. 1998. Successful Polish-English Translation. Tricks of the Trade. Warszawa: PWN.

[54] Kosiarz-Stolarska, A., Nieżgorodcew, A. 1995. Second and Foreign Language Acquisition. Kraków: Universitas.

[55] LeClercq, T. 2000. Expert Legal Writing. Austin: University of Texas Press.

[56] Legeżyńska, A. 1999. Ttumacz i jego kompetencje autorskie. Warszawa: PWN.

[57] Lipoński, W. 2001. Narodziny cywilizacji Wysp Brytyjskich. Poznań: Wydawnictwo Poznańskie.

[58] Lisowski, Z. 1948. Kilka uwag o języku polskich ustaw cywilnych. P.N. Vol. II, pp. 192-206.

[59] Lizisowa, M. T. 1986. Z badań nad terminologia prawna. Rocznik Naukowo-Dydaktyczny WSP Kraków, Prace Językoznawcze, Vol. 5, pp. 5-20.

[60] Locke, Ch., Russell, F., 1992. English Law and Language. London: Cassell Publishers Ltd.

[61] Lukszyn, J. 1993. Tezaurus terminologii translatorycznej. Warszawa: PWN.

[62] Maciejewski, T. 1998. Historia prawa sqqdowego Polski. Koszalin: Wydawnictwo Miscellanea.

[63] Macpherson, R. 1996. English for Writers and Translators. Warszawa: PWN.

[64] Malinowski, A. 1980. Właściwości statystyczne języka prawnego na tle właściwości języka potocznego. Państwo i Prawo, Vol. 9, pp. 67-76. 
[65] Mańczak-Wohlfeld, E., Willim, E. 1997. A Contrastive approach to Problems with English. Kraków: PWN.

[66] Marsh, S.B., Soulsby, J. 1990. Outlines of English Law. London: McGraw_Hill Book Company.

[67] Matulewska, A. 2002. Depozyt sqqdowy and Its Translation Equivalents. [In:] W. Krzemińska, P. Nowak (Eds) Przestrzenie informacji. Poznań: Sorus, pp. 185-194.

[68] Melliknoff, D. 1963. The Language of the Law. Boston-Toronto: Little, Brown and Company.

[69] Nowak, L. 1968. Performatywy a język prawny i etyczny. Etyka, Vol. 3, pp. 147-158.

[70] Okulicz-Kozaryn, Ł. 1993. Finowie Zachodni, Warszawa.

[71] Peczenik, A. 1969. Rodzaje analizy pojęć prawnych. Krakowskie studia prawnicze, Vol. 3-4.

[72] Pieńkom, J. 1999. Praecepta iuris. Łacina dla prawników. Terminy, paremie, wyrażenia w porządku systematycznym. Warszawa: Muza S.A.

[73] Pieńkos, J. 1999. Podstawy juryslingwistyki. Język w prawie - prawo w języku. Warszawa: Muza S.A.

[74] Piotrowska M. 1997. Learning Translation - Learning the Impossible. Kraków: TAiWPN Universitas.

[75] Raun, T. 1991. Estonia and the Estonians. Stanford.

[76] Riley, A. 1990. English for Law. UK: Longman.

[77] Robinson, P. 1991. ESP Today: a Practicioner's Guide. UK: Prentice Hall International Ltd.

[78] Roszkowski, S. 1999. The language of Law as Sublanguage. [In:] J. Tomaszczyk (Ed.) Aspects of Legal Language and Legal Translation. Łódź: Wydawnictwo Uniwersytetu Łódzkiego, pp. 7-16.

[79] Saareste, A. 1923. Eesti, eestlased ja Eesti keel/Eesti, die Esten und die estnische Sprache. Separadruck der Einleitung der dritten Auflage des Wörterbuch von F. Wiedemann, Tartu.

[80] Samsonowicz, H. 2000. Zakon krzyżacki, Prusy, Inflanty - ich miejsce w Europie Środkowo-Wschodniej, [In:] J. Kłoczowski (ed.) Historia Europy Środkowo-Wschodniej, Vol.2, Lublin.

[81] Sczaniecki, M. 1995. Powszechna historia państwa i prawa. Warszawa: PWN.

[82] Sourioux, J. L., Lerat, P. 1975. Le langage du droit. Presses Universitaires de France.

[83] Tannberg, T., Mäesalu A. 2000. History of Estonia, Tallinn.

[84] The Scottish Legal System - Legislature, http://www.law.gla.ac.uk/scot_guide/LEGIS.HTML 15. 04. 2002

[85] The Scottish Legal System Legal Aid, http://www.law.gla.ac.uk/scot_guide/LEGIS.HTML 15. 04. 2002.

[86] The Scottish Legal System, The Courts, Page last updated: 8 July 1998

[87] Tiersma, P.M. 1999. Lagal Language. Chicago - London: The University of Chicago Press.

[88] Tomaszczyk, J. (ed.) 1999. Aspects of Legal Language and Legal Translation. Łódź: University Press.

[89] Türk, K. 1998. Lendsõnade leksikon. Tallinn: Avita

[90] Uustalu, E. 1951. The History of Estonian People. London.

[91] Villems, R. 2000. On the Background of the Biological History of the Estonian Speaking People [In:] Estonia. Candidate for Membership in the European Union. Tallinn.

[92] Voellnagel, A. 1998. Jak nie ttumaczyć tekstów technicznych. Warszawa: TEPIS

[93] Walczak, B. 1995. Zarys dziejów języka polskiego. Poznań: Kantor Wydawniczy SAWW

[94] Waldenberg, M. 1992. Kwestie narodowościowe w Europie Środkowo-Wschodniej. Warszawa.

[95] Wierzchowski, J. 1990. Leksykalno-frazeologiczna struktura języka. Polska Akademia Nauk Komitet Językoznawstwa. Prace Językoznawcze 115. Ossolineum.

[96] Wojtasiewicz, O. 1996. Wstęp do teorii ttumaczenia. Warszawa: TEPIS.

[97] Woleński, J. 1967. Język prawny w świetle współczesnych metod analizy semantycznej. [In:] Zeszyty Naukowe UJ, Kraków, Prace Prawnicze, Vol. 31, pp. 141-156

[98] Wolter, W. 1972. Z problematyki języka prawnego kodeksu karnego. Krakowski Studia Prawnicze, R. 5:, s. 3-31

[99] Wróblewski, B. 1948. Język prawny i prawniczy. Polska Akademia Umiejętności. Prace Komisji Prawniczej nr 3, Kraków.

[100] Wróblewski, J. 1956. Wykładnia prawa a terminologia prawna. [In:] Państwo i Prawo. Vol. 5-6, pp. 843-865.

[101] Wróblewski, J. 1987. Zagadnienia polskiej terminologii prawnej i prawniczej. Studia Prawno-ekonomiczne, Vol. 39, pp. 17-34.

[102] Wróblewski, J. 1984. Zagadnienia terminologii nauk prawnych. Nauka Polska, Vol. 3, pp. 75-86.

[103] Yiannopoulos, A. N. 1996. Louisiana Civil Code. Minn: West Publishing Co.St. Paul.

[104] Zasady techniki prawodawczej. 1992. Uchwała Nr 147 Rady Ministrów z dnia 5 listopada 12991r. Warszawa: Wydawnictwo Sejmowe.

[105] Ziembiński, Z. 1964. Próba uporzq̨dkowania podstawowego słownictwa prawniczego. Studia Logica XVB.

[106] 1001 ladina sententsi eesti vastetega. 2000.Tallinn. 